\title{
PENERAPAN MODEL PEMBELAJARAN KOOPERATIF TIPE STRUKTURAL THINK-PAIR-SHARE (TPS) UNTUK MENINGKATKAN HASIL BELAJAR IPA
}

\author{
Mory Victor Febrianto ${ }^{1)}$ \\ 1) Universitas Abdurachman Saleh Situbondo \\ mory_victor86@yahoo.com
}

\begin{abstract}
ABSTRAK: IPA sebagai salah satu ilmu dasar, baik aspek terapan maupun aspek penalaran mempunyai peranan yang penting dalam upaya penguasaan ilmu dan teknologi. Ini berarti bahwa sampai batas tertentu IPA perlu dikuasai oleh segenap warga, baik penerapan maupun pola pikirnya. Observasi awal bahwa di SDN 9 Patokan, ditentukan suatu permasalahan dalam pembelajaran IPA pokok bahasan Daur Hidup Hewan. Hal ini teramati melalui hasil observasi yang menunjukkan bahwa dari hasil ulangan harian siswa, sebanyak 50\% dari 12 siswa di kelas IV mencapai nilai kurang dari 65 , yang berarti daya serap klasikal masih dibawah standar $50 \%$ dari 12 siswa. hasil tes akhir pada pelaksanaan siklus II, dapat diketahui bahwa ketuntasan hasil siswa sudah tercapai, karena terdapat 12 siswa (100\%) yang mencapai nilai $\geq 65$. Nilai 65 ini merupakan KKM yang telah ditentukan oleh sekolah. Ketuntasan belajar siswa ini telah mengalami peningkatan, karena pada siklus I hanya ada 9 siswa (75\%) siswa yang mencapai nilai $\geq 65$.
\end{abstract}

Kata kunci : Model Pembelajaran, Tipe Struktural Think-Pair-Share, Hasil Belajar

ABSTRACT: Science as one of the basic sciences, both applied aspects and reasoning aspects, has an important role in the effort to master science and technology. This means that to a certain extent science needs to be mastered by all citizens, both in terms of implementation and mindset. Initial observations were that at SDN 9 Patokan, a problem was determined in science learning the subject of the Animal Life Cycle. This was observed through the results of observations which showed that from the results of the students' daily tests, as many as 50\% of the 12 students in grade IV reached a score of less than 65, which means that classical absorption is still below the standard of $50 \%$ of 12 students. The final test results in the implementation of cycle II, it can be seen that the completeness of student results has been achieved, because there are 12 students (100\%) who achieved a value of $\geq 65$. This value of 65 is the KKM that has been determined by the school. The completeness of these students' learning has increased, because in the first cycle there were only 9 students (75\%) of students who achieved a value of $\geq 65$.

Keywords: Learning Model, Think-Pair-Share Structural Type, Learning Outcomes

\section{PENDAHULUAN}

Guru adalah salah satu yang memegang kunci dalam pendidikan dan pengajaran di sekolah dan guru merupakan unsur yang paling dekat dalam hubungan dengan siswa, sehingga peranan guru banyak menentukan keberhasilan siswa dalam mencapai tujuan pembelajaran yang akan berpengaruh pada hail belajar siswa. Oleh karena itu guru harus benar-benar mengetahui keadaan siswa dan cara pengelolaan kelas secara baik. Guru harus dapat mengkondisikan keadaan kelas agar suasana kelas menjadi nyaman dan tidak menjemukan atau membosankan. Menciptakan suasana belajar yang memberi kepuasan dan kesenangan pada siswa dan usaha lain dipandang pantas dilakukan untuk memenuhi kebutuhan untuk belajar siswa (Sagala, 2007). Guru harus mengerti metode dan strategi apa yang sesuai dalam menyampaikan materi pelajaran khususnya pelajaran IPA. 
Dilain pihak, rendahnya semangat belajar merupakan penyebab tersendiri terhadap hasil belajar siswa, seperti yang diketahui bahwa semangat merupakan salah satu faktor yang menimbulkan gairah dan perasaan senang terhadap materi pelajaran IPA yang disampaikan oleh guru. Untuk mewujudkan hal tersebut pembelajaran yang dilakukan sedemikian rupa sehingga setiap siswa melihat bahwa IPA penting baginya dalam menghadapi masa depannya yang penuh masalah pelik yang perlu diselesaikan dengan cara berpikir kreatif. Siswa perlu disandarkan bahwa tanggung jawab terhadap hasil belajarnya ada di tangan mereka, sedangkan guru bertanggung jawab pada penciptaan proses pembelajaran yang memungkinkan siswa memperoleh pengalaman belajar yang optimal. Siswalah yang mengkonstruksi pengetahuan dalam pikirannya, guru membantu dan memfasilitasi.

IPA sebagai salah satu ilmu dasar, baik aspek terapan maupun aspek penalaran mempunyai peranan yang penting dalam upaya penguasaan ilmu dan teknologi. Ini berarti bahwa sampai batas tertentu IPA perlu dikuasai oleh segenap warga, baik penerapan maupun pola pikirnya. Pendidikan Ilmu Pengetahuan Alam merupakan bagian dari pendidikan yang mengembangkan tujuannya dari tujuan pendidikan secara umum. Dalam proses belajar mengajar diperlukan kualitas pengajaran yang memadai, yaitu pengajaran IPA yang diarahkan untuk membantu siswa menggunakan daya intelektual dalam belajar. Menurut Nasution (2006) yang beranggapan bahwa interaksi kita dengan lingkungan sekeliling kita selalu menggunakan kategori-kategori. Dengan menggunakan kategorikategori akan membantu siswa untuk menggunakan daya intelektual dalam belajar dengan menerapkan pada lingkungan sekitarnya.

\section{Identifikasi Masalah}

Berdasarkan observasi awal bahwa di SDN 9 Patokan, ditentukan suatu permasalahan dalam pembelajaran IPA pokok bahasan Daur Hidup Hewan. Hal ini teramati melalui hasil observasi yang menunjukkan bahwa dari hasil ulangan harian siswa, sebanyak 50\% dari 12 siswa di kelas IV mencapai nilai kurang dari 65, yang berarti daya serap klasikal masih dibawah standar 50\% dari 12 siswa. Keadaan ini diperparah lagi dengan penggunaan metode pembelajaran yang dipakai guru pada saat kegiatan belajar mengajar berlangsung.

\section{Analisis Masalah}

Metode yang dipakai guru dalam mengajar yaitu metode pembelajaran konvensional dengan sistem ceramah. Dengan didominasinya pembelajaran menggunakan metode ceramah kegiatan belajar mengajar di dalam kelas menjadi pasif. Hal ini dapat dilihat dari jarangnya peserta didik mengajukan pertanyaan, serta anggapan siswa bahwa IPA adalah pelajaran yang paling sulit. Adanya serangkaian permasalahan di atas menyebabkan proses kegiatan belajar mengajar tidak sesuai dengan yang diharapkan yaitu siswa mampu berpikir kreatif. 
Dewasa ini muncul berbagai metode pembelajaran sebagai pilihan bagi guru dalam mengajar, sehingga kreatifitas guru dituntut dalam menerapkan metode pembelajaran yang dipilih. Salah satu alternatif metode pembelajaran IPA adalah Pendekatan struktural TPS yang dikembangkan oleh Kagan dalam (Lie, A, 2002) ini mengajarkan siswa untuk lebih mandiri dalam mengerjakan soal-soal yang diberikan sehingga dapat membangkitkan rasa percaya diri siswa, dimana siswa dapat bekerja sama orang lain dalam kelompok kecil yang heterogen. Keunggulan dari pendekatan ini adalah optimalisasi partisipasi siswa, selain itu siswa mampu menjelaskan pokok bahasan Daur Hidup Hewan dan menghendaki siswa untuk lebih banyak berfikir, menjawab, dan saling membantu dalam kelompok kecil yang heterogen baik secara akademik maupun jenis kelamin. Kelompok kecil ini diharapkan siswa lebih aktif belajar untuk menyelesaikan tugas-tugas akademik dan semua anggota kelompok merasa terlibat didalamnya. Untuk menanggulangi permasalahan di atas diterapkanlah Pendekatan Struktural Think-PairShare (TPS).

\section{METODE PENELITIAN}

Penelitian ini termasuk jenis Penelitian TindakanKelas (PTK) yangmenggunakanmetode deskriptif kualitatif. Penelitian tidakankelas ini dilakukan di kelaspeneliti yaitu siswa kelas IV SDN 9 Patokan dengan tujuan untuk memperbaiki atau meningkat hasil belajar IPA siswa. PenelitianTindakan Kelas (PTK) adalah penelitian yang dilakukan oleh guru di kelas atau di sekolah tempat ia mengajardengan penekanan pada penyempurnaan atau peningkatan proses dan hasil pembelajaran (Arikunto,2010:135).

\section{Desain Prosedur Perbaikan Pembelajaran}

Desain penelitian yang dipakai dalam penelitian ini adalah model skema spiral dari Hopkins (dalam Tim Proyek PGSM, 2006) dengan menggunakan empat fase yaitu: perencanaan, tindakan, observasi dan refleksi. Keempat fase tersebut merupakan suatu siklus untuk melaksanakan penelitian tindakan kelas ditunjukkan dengan bagan berikut:

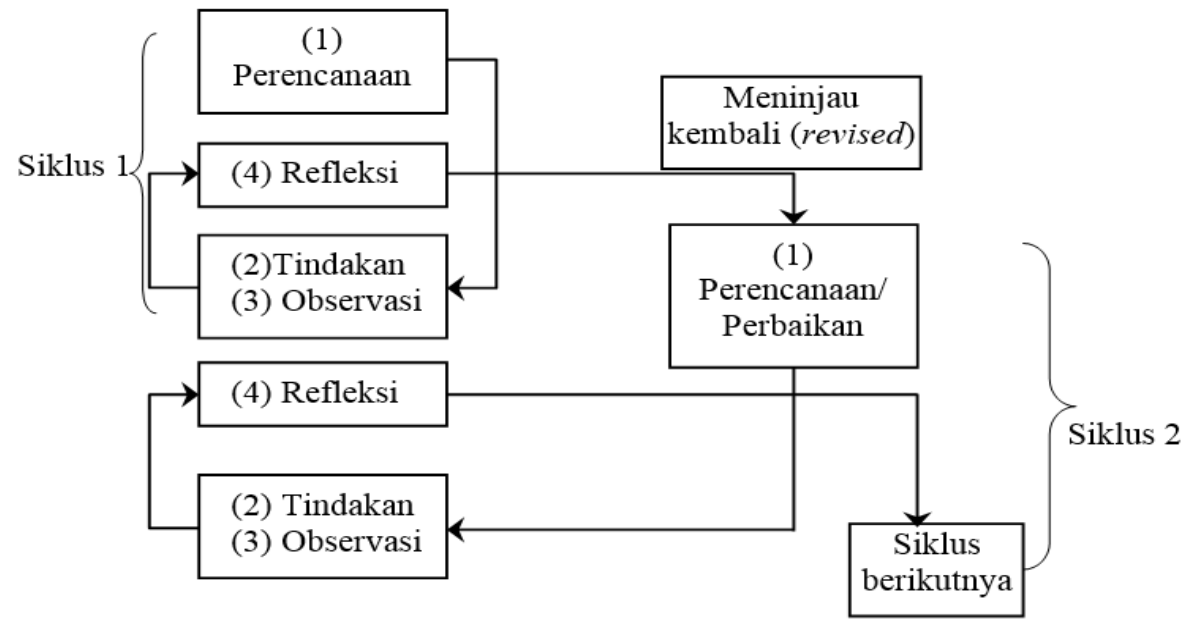

Gambar 1. (Hopkins dalam Tim Proyek PGSM, 2006) 
Hal-hal mengenai rencana pelaksanaan siklus tersebut diuraikan sebagai berikut:

\section{Siklus I}

\section{Perencanaan}

Tahap ini merupakan tahap merencanakan segala sesuatu yang akan dilakukan dalam penelitian. Kegiatan yang dilakukan dalam tahap perencanaan ini adalah sebagai berikut:

a. Menetapkan dan memilih pokok bahasan dengan pelaksanaan dua siklus.

b. Menyusun program silabus dan rencana pembelajaran untuk masing-masing pokok bahasan yang mengacu pada penerapan model pembelajaran kooperatif tipe TPS.

c. Menentukan kelompok belajar siswa

d. Membuat soal-soal pertanyaan untuk ulangan harian.

e. Membuat lembar observasi yang digunakan peneliti untuk mengamati hasil belajar siswa.

\section{Tindakan}

Hal-hal yang dilakukan peneliti pada pelaksanaan tindakan ini adalah peneliti berperan sebagai guru dan peneliti melakukan tindakan berdasarkan pada perencanaan yang telah dibuat. Tindakan yang dilakukan difokuskan pada upaya meningkatkan hasil belajar siswa dari rendah menjadi tinggi dengan menerapkan model pembelajaran kooperatif tipe TPS. Pada siklus I ini peneliti melaksanakan tindakan.

a. Kegiatan Awal

1) Guru menyapa siswa dan mengondisikan kelas agar siap untuk belajar.

2) Seorang siswa diminta untuk memimpin doa.

3) Guru mengingatkan siswa tentang pelajaran sebelumnya dan mengaitkan dengan pelajaran yang akan disampaikan.

4) Guru menjelaskan kegiatan yang akan dilakukan dan tujuan kegiatan belajar.

b. Kegiatan Inti

1) Guru menyajikan materi secara klasikal.

2) Berikan persoalan (problem) berupa pendalaman, perluasan, dan aplikasi.

3) Tugaskan siswa secara berpasangan untuk membahasnya (Think Pair).

4) Presentasikan hasil kelompok (Share).

5) Kuis individual buat skor perkembangan tiap siswa.

6) Umumkan hasil kuis

c. Kegiatan Akhir

1) Sebagai penutup guru mereview semua kegiatan yang sudah dilakukan seharian

2) Guru meminta siswa melakukan refleksi kegiatan hari itu dengan bertanya : bagaimana perasaan kalian mengikuti pembelajaran hari ini? Kegiatan apa yang kamu sukai? Mengapa?, Kegiatan mana yang paling mudah/sulit? Mengapa ?

3) Kelas ditutup dengan doa bersama. 


\section{Observasi}

Peneliti dibantu oleh dua orang teman dan guru kelas untuk mengamati perubahan tingkat hasil belajar pada siswa saat peneliti mengimplementasikan tindakan. Hal ini dimaksudkan untuk menghindari subjektifitas dari peneliti sehingga data yang dihasilkan sesuai dengan keadaan yang sebenarnya.

\section{Refleksi}

Tahap refleksi ini merupakan tahap yang dilakukan peneliti untuk menilai hasil kegiatan belajar siswa dari tindakan yang telah dilaksanakan. Peneliti melakukan refleksi dengan cara mengevaluasi hasil belajar siswa dengan model pembelajaran kooperatif tipe TPS yang telah dilaksanakan. Dengan melakukan refleksi peneliti dapat mengetahui kekurangan kegiatan belajar mengajar yang dilakukan oleh peneliti sehingga dapat digunakan untuk menentukan tindakan perbaikan pada siklus berikutnya. Pelaksanaan pada refleksi untuk mengetahui kelemahan dan kelebihan pada saat penerapan model pembelajaran kooperatif tipe TPS .

\section{Siklus II}

\section{Perencanaan}

Tahap ini merupakan tahap merencanakan segala sesuatu yang akan dilakukan dalam penelitian. Kegiatan yang dilakukan dalam tahap perencanaan ini adalah sebagai berikut:

a. Melaksanakan siklus kedua.

b. Melaksanakan silabus dan rencana pembelajaran untuk masing-masing materi mengacu penerapan model pembelajaran kooperatif tipe TPS.

c. Menentukan kelompok belajar siswa

d. Melaksanakan soal-soal pertanyaan untuk ulangan harian.

e. Melaksanakan lembar observasi yang digunakan peneliti untuk mengamati hasil belajar siswa.

\section{Tindakan}

Tindakan yang dilakukan difokuskan pada upaya meningkatkan hasil belajar siswa dari rendah menjadi tinggi dengan menerapkan model pembelajaran kooperatif tipe TPS. Pada siklus II ini peneliti melaksanakan tindakan. Pada siklus II merupakan perbaikan dari siklus I dengan mengembangkan materi IPA.

a. Kegiatan Awal

1) Guru menyapa siswa dan mengondisikan kelas agar siap untuk belajar.

2) Seorang siswa diminta untuk memimpin doa.

3) Guru mengingatkan siswa tentang pelajaran sebelumnya dan mengaitkan dengan pelajaran yang akan disampaikan.

4) Guru menjelaskan kegiatan yang akan dilakukan dan tujuan kegiatan belajar.

b. Kegiatan Inti

1) Guru menympaikan inti materi dan kompetensi yang ingin dicapai 
2) Siswa diminta untuk berfikir tentang materi atau pemasalahan yang disampaikan guru

3) Siswa diminta berpasangan dengan teman sebelahnya (2 orang) dan mengutarakan hasil pemikirannya masing-masing

4) Siswa diminta berpasangan lagi dengan teman belakangnya (4 orang) untuk mendiskusikan lagi hasil jawabannya

5) Guru memimpin pleno diskusi kecil tersebut, tiap kelompok mengemukakan hasil diskusinya

6) Berawal dari kegiatan tersebut, guru mengarahkan pembicara pada pokok pembicaraan.

c. Kegiatan Akhir

1) Sebagai penutup guru mereview semua kegiatan yang sudah dilakukan seharian

2) Guru meminta siswa melakukan refleksi kegiatan hari itu dengan bertanya : bagaimana perasaan kalian mengikuti pembelajaran hari ini? Kegiatan apa yang kamu sukai? Mengapa?, Kegiatan mana yang paling mudah/sulit? Mengapa ?

3) Kelas ditutup dengan doa bersama.

\section{Observasi}

Peneliti dibantu oleh dua orang teman dan guru kelas untuk mengamati perubahan tingkat hasil belajar pada siswa saat peneliti mengimplementasikan tindakan. Hal ini dimaksudkan untuk menghindari subjektifitas dari peneliti sehingga data yang dihasilkan sesuai dengan keadaan yang sebenarnya.

\section{Refleksi}

Tahap refleksi ini merupakan tahap yang dilakukan peneliti untuk mengkaji kelemahan dan kelebihan dalam model pembelajaran kooperatif tipe TPS. Jika siklus kedua telah tuntas maka tidak perlu diadakan siklus II.

\section{Pengumpulan Data}

Metode pengumpulan data adalah cara-cara yang digunakan untuk mengumpulkan data. Ada beberapa cara yang dapat digunakan untuk mengumpulkan data antara lain: observasi, wawancara dan tes.

\section{Metode Observasi}

Kegiatan observasi dilakukan bersama-sama dengan pelaksanaan tindakan. Observasi dilakukan untuk mengetahui secara langsung hasil belajar siswa Kelas 4 di SDN 9 Patokan pada mata pelajaran IPA. Dalam melakukan observasi peneliti dibantu oleh tiga orang teman dengan menggunakan lembar observasi yang telah dipersiapkan sebelumnya. Kegiatan yang dilakukan selama observasi adalah mengamati secara langsung kemudian menilai aktivitas siswa yang berkaitan dengan aktifitas belajar siswa. 


\section{Metode Wawancara}

Wawancara dilakukan pada perwakilan siswa Kelas 4 di SDN 9 Patokan yang telah dipilih oleh peneliti sebanyak tiga orang yaitu siswa yang mempunyai aktifitas belajar cukup, dan tidak aktif, mengenai tanggapan siswa terhadap penerapan model pembelajaran kooperatif tipe TPS. Wawancara terhadap guru Kelas 4 juga dilakukan untuk mengetahui tanggapan guru terhadap pembelajaran yang telah diterapkan peneliti. Data yang diperoleh dari metode wawancara ini adalah sebagai pelengkap dari semua data yang telah dikumpulkan.

3. Tes

Tes yang digunakan dalam penelitian ini berupa tes formatif yang meliputi tes uraian (essay) yang menuntut siswa menjawab dalam bentuk uraian. Tes akhir dibuat dalam bentuk tes uraian (essay) yang terdiri dari 5 soal.

\section{Dokumentasi}

Metode dokumentasi digunakan untuk memperoleh data yang berasal dari bukti tertulis di SDN 9 Patokan. Dalam penelitian ini data tersebut diperoleh dari kepala sekolah dan Wali Kelas 4, jumlah siswa Kelas4, presentasi Kelas 4, dan data-data yang lain yang dapat menunjang penelitian. Data yang diperoleh tersebut tidak untuk dianalisis melainkan digunakan untuk melengkapi data-data yang diperlukan.

\section{Teknis Analisis Data}

Penelitian ini menggunakan analisis deskriptif kualitatif untuk menganalisis data. Data kualitatif diperoleh dari hasil observasi awal sebelum tindakan dan observasi pada saat peneliti melaksanakan tindakan, yaitu hasil observasi mengenai penilaian hasil belajar siswa. Untuk mengkategorikan tingkah laku siswa selama pelaksanaan tindakan, peneliti menggunakan lembar observasi berdasarkan Sukarni (2001:429) tentang aspek yang harus diamati dalam penggunaan model pembelajaran kooperatif tipe TPS. Ketuntasan belajar dapat menggunakan rumus sebagai berikut:

$$
\mathrm{P}=\frac{n}{N} \times 100 \%
$$

Keterangan:

$\mathrm{P}$ : Tingkat ketuntasan belajar

$\mathrm{N}$ : jumlah semua siswa

$\mathrm{n}$ : jumlah siswa yang tuntas belajarnya

Setelah nilai hasil belajar di presentasikan kemudian dicari standar ketuntasan untuk mengetahui daya serap siswa secara individu dan klasikal standar tersebut yaitu:

a. Ketuntasan perseorang : Seorang siswa dikatakan telah memenuhi standar ketuntasan belajar bila mencapai nilai $\geq 65$

b. Ketuntasan klasikal : Suatu kelas dikatakan telah memenuhi standar ketuntasan belajar di kelas tersebut telah mencapai $\geq 85 \%$ dari jumlah siswa yang telah mencapai nilai $\geq 65$. 


\section{HASIL PENELITIAN DAN PEMBAHASAN Hasil Penelitian}

Untuk mengetahui hasil dari suatu penelitian diperlukan pemaparan data yang diperoleh dari lapangan. Paparan data tersebut akan disajikan dan disesuaikan dengan prosedur penelitian yang ada pada bab III. Paparan data ini terdiri dari: (1) Paparan data pra tindakan; (2) Paparan data pada siklus I; (3) Paparan data pada siklus II.

\section{Paparan Data Pra Tindakan}

Sebelum penelitian dilaksanakan, peneliti terlebih dahulu mengajukan izin ke kepala SDN 9 Patokan pada tanggal 2 Maret 2020, untuk melaksanakan penelitian di sekolah tersebut. Setelah kepala SDN 9 Patokan memberi izin, peneliti langsung mengadakan wawancara dengan guru kelas 4 untuk menentukan kelas mana yang akan dijadikan subyek penelitian. Akhirnya peneliti memutuskan untuk memilih kelas 4 sebagai subyek penelitian. Peneliti mengambil kelas tersebut dengan pertimbangan hasil wawancara peneliti dengan guru IPA yang menyatakan bahwa berdasarkan pengamatan guru kelas 4 terhadap proses pembelajaran dan hasil ulangan harian siswa tersebut: (1) Siswa kelas 4 kelihatan pasif dibandingkan dengan kelas lainnya, (2) Tidak pernah mengadakan kegiatan TPS dengan media boneka media tiga dimensi, karena masih terbatasnya sarana dan prasarana yang tersedia, (3) Siswa jarang sekali mengajukan pertanyaan pada saat pembelajaran berlangsung, keadaan seperti ini menggambarkan rendahnya rasa ingin tahu siswa dan berujung pula pada rendahnya kemampuan berpikir kreatif siswa, (4) Hasil belajar siswa kelas IV tergolong rendah, hal ini dapat dilihat dari rata-rata kelas ulangan harian siswa sebesar 58,75.

Tabel 1. Hasil Prasiklus

\begin{tabular}{|c|c|c|}
\hline Siswa yang mendapat nilai & Jumlah siswa & Persentase \\
\hline Siswa yang mendapat nilai $>65$ & 5 & $40 \%$ \\
\hline Siswa yang mendapat nilai $<65$ & 7 & $60 \%$ \\
\hline
\end{tabular}

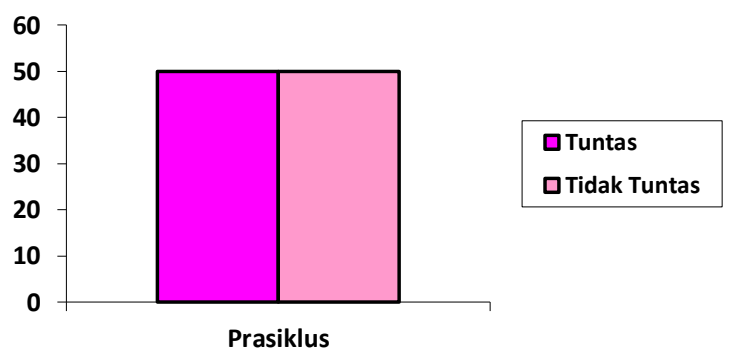

Gambar 2. Hasil Belajar siswa Prasiklus

\section{Tahap Observasi}

Selama pembelajaran, peneliti tidak terlepas dengan bantuan teman sejawat, karena teman sejawat merupakan observer yang membantu mengamati proses pembelajaran dan mencatat hal penting selama kegiatan pembelajaran berlangsung. Hasil 
observasi pengamat terhadap pelaksanaan pembelajaran juga menunjukkan bahwa pembelajaran sudah berlangsung dengan baik. Pada observasi ini peneliti dibantu oleh satu orang pengamat, kemudian menugaskan siswa untuk mencatat hal-hal yang dianggap penting dari pelaksanaan TPS. Memulai TPS kegiatan-kegiatan yang merancang kegiatan siswa untuk berpikir. Menciptakan suasana yang menyejukkan dengan menghindari suasana yang menegangkan.

Tabel 2. Hasil Siklus I

\begin{tabular}{|l|l|l|}
\hline Siswa yang mendapat nilai & Jumlah siswa & Persentase \\
\hline Siswa yang mendapat nilai $>65$ & 9 & $75 \%$ \\
\hline Siswa yang mendapat nilai $<65$ & 3 & $25 \%$ \\
\hline
\end{tabular}

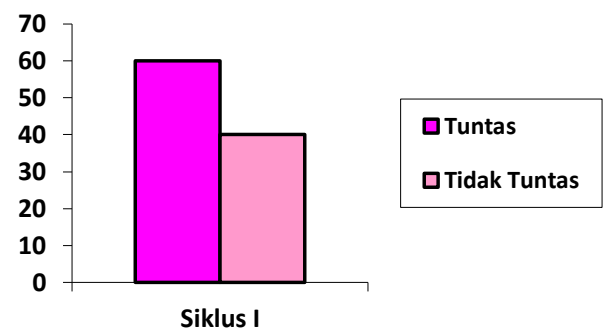

Gambar 3. Hasil Belajar siswa Siklus I

\section{Refleksi}

Model pembelajaran TPS telah memberikan suatu kelebihan dan kekurangan. Kelebihannya yaitu media yang digunakan dapat menarik siswa, sehingga dapat memfasilitasi siswa menuangkan ide-ide kreatifnya dalam melakukan praktek. Adapun kelemahan model pembelajaran pada siklus I adalah sebagai berikut: (1) Model pembelajaran yang digunakan membutuhkan waktu yang lama; (2) Pada pembelajaran I siswa tidak mencatat hal-hal yang dianggap penting dari pelaksanaan TPS; (3) Pada pembelajaran II siswa tidak memberi banyak gagasan dalam menyelesaikan masalah; (4) Suasana nampak gaduh; (5) Dari hasil tes yang telah diberikan masih 25\% siswa atau sebanyak 3 siswa yang tidak tuntas dalam belajarnya, karena belum memenuhi KKM yang telah ditetapkan dari pihak sekolah adalah sebesar $85 \%$ yang mendapat nilai $\geq 65$, ini berarti ketuntasan belum memenuhi KKM; (6) mencapai 60\%. KKM yang telah ditetapkan dari pihak sekolah adalah sebesar 85\% ini berarti ketuntasan belum memenuhi KKM yang telah di tetapkan dari pihak kepala sekolah, karena siswa yang tuntas $\leq 85 \%$.

Dengan demikian peneliti perlu melanjutkan siklus berikutnya. Oleh karena itu dalam pembelajaran selanjutnya kelebihan pada pembelajaran siklus I di pertahankan dan memperbaiki kekurangan pada siklus I. Hal yang perlu diperbaiki yaitu mencatat hal-hal yang dianggap penting dari pelaksanaan TPS dan menanggapi dan bertanya pada siswa yang model pembelajaran TPS. 
Kekurangan pada siklus I yaitu Membutuhkan koordinasi secara bersamaan dari berbagai aktivitas. Membutuhkan perhatian khusus dalam penggunaan ruangan kelas. Peralihan dari seluruh kelas ke kelompok kecil dapat menyita waktu pengajaran yang berharga. Untuk itu guru harus dapat membuat perencanaan yang seksama sehingga dapat meminimalkan jumlah waktu yang terbuang. Banyak kelompok yang melapor dan perlu dimonitor. Lebih sedikit ide yang muncul. Jika ada perselisihan,tidak ada penengah. Menggantungkan pada pasangan. Jumlah siswa yang ganjil berdampak pada saat pembentukan kelompok, karena ada satu siswa tidak mempunyai pasangan. Ketidaksesuaian antara waktu yang direncanakan dengan pelaksanaannya. Metode pembelajaran Think-Pair-Share belum banyak diterapkan di sekolah.

\section{Pelaksanaan Tindakan II}

Pelaksanaan tindakan II ini terdiri dari dua kali tatap muka yakni pembelajaran I dan tes. Pelaksanaan tindakan pembelajaran I ini merupakan perbaikan dari pembelajaran pada siklus I. Pelaksanaan tindakan pembelajaran I dilaksanakan sesuai dengan pelaksanaan pembelajaran, sebagai wujud dari model pembelajaran TPS.

\section{Observasi}

Selama pembelajaran, peneliti tidak terlepas dengan bantuan teman sejawat, karena teman sejawat merupakan observer yang membantu mengamati proses pembelajaran dan mencatat hal penting selama kegiatan pembelajaran berlangsung. Pada observasi ini peneliti dibantu oleh satu orang pengamat. Hasil observasi pengamat terhadap pelaksanaan pembelajaran juga menunjukkan bahwa pembelajaran sudah berlangsung dengan baik.

Hasil observasi pengamat meliputi aktivitas guru dan siswa dalam pembelajaran. Untuk lebih jelasnya hasil observasi pengamat terhadap aktivitas guru dalam pembelajaran dapat dipaparkan sebagai berikut: Mengatur tempat duduk yang memungkinkan semua siswa dapat memperhatikan dengan jelas apa yang model pembelajaran TPS. Mengemukakan tujuan apa yang harus dicapai oleh siswa. Menugaskan siswa untuk mencatat hal-hal yang dianggap penting dari pelaksanaan TPS. Memulai TPS dengan kegiatan-kegiatan yang merancang kegiatan siswa untuk berpikir. Menciptakan suasana yang menyejukkan dengan menghindari suasana yang menegangkan. Meyakinkan bahwa semua siswa mengikuti jalannya TPS memperhatikan reaksi seluruh siswa. Memberikan kesempatan kepada siswa untuk secara aktif memikirkan lebih lanjut sesuai apa yang dilihat dari proses TPS.

Berdasarkan data observasi terhadap kegiatan guru dan siswa, dapat disimpulkan bahwa kegiatan guru dalam mengajar dan kegiatan siswa dalam belajar sudah sangat baik dan sesuai dengan yang direncanakan. 


\section{Refleksi}

Siklus II merupakan perbaikan dari siklus I. Pada tahap ini tidak ditemukan permasalahan-permasalahan atau hambatan yang berarti. Jika dilihat dari pelaksanaan pembelajaran yang dilakukan oleh guru semua indikator yang telah dirancang sepenuhnya sudah dijalankan sesuai prosedur. Sedangkan ketuntasan belajar siswa sudah mencapai 85\% atau sebanyak 12 siswa yang tuntas. Berdasarkan KKM yang telah ditetapkan dari pihak sekolah adalah sebesar 100\% ini berarti ketuntasan belajar siswa sudah mencapai kategori baik, karena siswa yang tuntas $\geq 85 \%$. Dengan demikian peneliti tidak perlu melanjutkan siklus berikutnya.

Tabel 3. Hasil Siklus II

\begin{tabular}{|l|l|l|}
\hline Siswa yang mendapat nilai & Jumlah siswa & Persentase \\
\hline Siswa yang mendapat nilai $>65$ & 12 & $100 \%$ \\
\hline Siswa yang mendapat nilai $<65$ & 0 & $0 \%$ \\
\hline
\end{tabular}

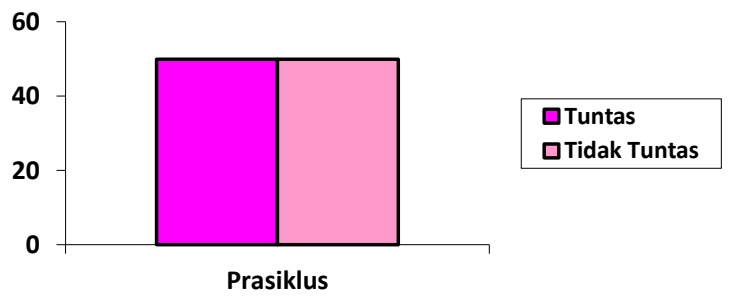

\section{PEMBAHASAN}

Gambar 4. Hasil Belajar siswa Siklus 2

Berdasarkan hasil wawancara yang diperoleh sebelum mengadakan penelitian diketahui mayoritas siswa kelas II cenderung pasif dalam melaksanakan pembelajaran. Hal ini menunjukkan rendahnya minat dan motivasi belajar siswa sehingga tingkat pola berpikir kreatifnya juga cenderung rendah.

Berdasarkan kondisi yang tersebut di atas, maka peneliti merencanakan pembelajaran dengan menggunakan model pembelajaran TPS. Hal ini dilakukan peneliti agar siswa lebih berminat dan termotivasi dalam belajar sehingga hasil belajar meningkat. Pembelajaran dengan model ini diharapkan siswa akan lebih senang dan tidak bosan dalam belajar, siswa akan terangsang untuk belajar bila melihat situasi belajar yang cenderung menarik. Hal ini disebabkan dalam model pembelajaran TPS menekankan pada kegiatan memperagakan dan mempertunjukkan tentang suatu proses, situasi atau benda tertentu. Sehingga model pembelajaran TPS dapat meningkatkan hasil belajar siswa, karena pada pembelajaran ini siswa lebih lebih banyak bekerja dari pada sekedar mendengarkan dan menerima informasi.

Beberapa data pengamatan setelah diberi tindakan pada siklus I dan siklus II guru mengungkapkan perubahan yang terjadi pada siswa. Perubahan tersebut adalah sebagai berikut: (1) Model pembelajaran TPS yang dilakukan pada kegiatan TPS memberikan reaksi yang sangat antusias pada siswa; (2) Media yang dibawa guru mampu menarik perhatian dan menimbulkan rasa ingin tahu siswa sehingga dapat memotivasi 
siswa untuk mengajukan pertanyaan;(3) Dalam proses belajar mengajar dengan model pembelajaran TPS dapat meningkatkan pola pikir kreatif siswa sehingga berdampak juga pada hasil belajar siswa yang juga semakin meningkat.

Perubahan positif yang terjadi pada siswa di atas tidak terlepas dari peran media pembelajaran yang digunakan pada saat pembelajaran berlangsung. Siswa merasa senang untuk belajar karena mereka belajar langsung dari pengalamannya dalam hal belajar sambil TPS. Berikut perolehan dari penerapan model pembelajaran TPS untuk meningkatkan hasil belajar IPA siswa kelas 4 SDN 9 Patokan dapat dijabarkan sebagai berikut:

1) Penerapan Model Pembelajaran TPS untuk meningkatkan hasil belajar siswa.

Penerapan model pembelajaran TPS dilaksanakan dalam dua tahapan yakni: (1) Tahap persiapan, pada tahap ini guru menjelaskan tujuan yang harus dicapai oleh siswa setelah proses TPS berakhir, Mempersiapkan bahan-bahan yang akan digunakan dalam TPS yang akan dilakukan dan melakukan uji coba TPS, dan melakukan uji coba TPS. (2) Tahap pelaksanaan, dalam tahap ini ada tiga langkah, yaitu langkah pembukaan, langkah pelaksanaan dan langkah mengakhiri TPS. (a) langkah pembukaan, pada langkah ini guru mengatur tempat duduk yang memungkinkan semua siswa dapat memperhatikan dengan jelas apa yang di TPS, mengemukakan tujuan apa yang harus dicapai oleh siswa, mengemukakan tugas-tugas apa yang harus dilakukan oleh siswa; (b) langkah pelaksanaan TPS, pada langkah ini guru memulai TPS dengan kegiatan-kegiatan yang merancang siswa untuk berpikir, menciptakan suasana yang menyejukkan dengan menghindari suasana yang menegangkan, meyakinkan bahwa semua siswa mengikuti jalannya TPS dengan memperhatikan reaksi seluruh siswa, memberikan kesempatan kepada siswa untuk secara aktif memikirkan lebih lanjut sesuai dengan apa yang dilihat dari proses TPS itu; (c) langkah mengakhiri TPS, pada langkah ini guru memberikan tugas-tugas tertentu yang ada kaitannya dengan pelaksanaan TPS dari proses pencapaian tujuan pembelajaran dan melakukan evaluasi bersama tentang jalannya proses TPS itu untuk perbaikan selanjutnya.

Berdasarkan hasil pengamatan yang dilakukan, proses pembelajaran model TPS semakin meningkat $75 \%$ menjadi $100 \%$. Kenaikan termasuk kategori sangat baik. Peningkatan ini dikarenakan siswa diberikan ruang seluas-luasnya untuk mengekspresikan dirinya dalam menyelesaikan masalah, peningkatan ini terlihat dari banyaknya siswa yang berani menyampaikan gagasan atau pertanyaan pada saat pembelajaran berlangsung.

2) Hasil Belajar Siswa

Berdasarkan hasil tes akhir pada pelaksanaan siklus II, dapat diketahui bahwa ketuntasan hasil siswa sudah tercapai, karena terdapat 12 siswa (100\%) yang mencapai nilai $\geq 65$. Nilai 65 ini merupakan KKM yang telah ditentukan oleh sekolah. 
Ketuntasan belajar siswa ini telah mengalami peningkatan, karena pada siklus I hanya ada 9 siswa $(75 \%)$ siswa yang mencapai nilai $\geq 65$.

Tabel 4. Perbandingan Hasil Belajar

\begin{tabular}{|c|c|c|c|}
\hline Siswa Yang Mendapat Nilai & Prasiklus & Siklus I & Siklus II \\
\hline Siswa yang mendapat nilai $>65$ & $50 \%$ & $75 \%$ & $100 \%$ \\
\hline Siswa yang mendapat nilai $<65$ & $50 \%$ & $25 \%$ & $0 \%$ \\
\hline
\end{tabular}

Dari penjelasan di atas, maka model pembelajaran TPS merupakan salah satu bentuk inovasi dalam memperbaiki kualitas proses belajar mengajar yang bertujuan untuk membantu siswa agar bisa belajar mandiri dan kreatif, sehingga siswa dapat memperoleh pengetahuan, keterampilan dan sikap yang dapat membentuk kepribadian siswa.

\section{KESIMPULAN}

\section{Kesimpulan}

Berdasarkan hasil yang telah dilakukan dapat ditarik kesimpulan sebagai berikut: penerapan model pembelajaran kooperatif tipe struktural think-pair-share (TPS) dapat meningkatkan hasil belajar IPA siswa SDN 9 Patokan. pelaksanaan siklus I dari data pra siklus $60 \%$ belum tuntas yaitu 6 anak setelah menggunakan TPS menjadi meningkat 9 siswa $(75 \%)$ siswa yang mencapai nilai $\geq 65$.

Pada siklus II juga dilakukan kegiatan pembelajaran dengan menggunakan TPS, dimana pada siklus I sudah ada 9 siswa yang sudah tuntas, pada siklus 2 ini dilakukan perbaikan pembelajaran dimana pada siklus II ini dari 12 siswa kelas 4 ini sudah memiliki nilai diatas 65 , karena terdapat 12 siswa $(100 \%)$ yang mencapai nilai $\geq 65$. Jadi bisa dikatakan bahwa siklus 1 dan siklus II sudah meningkat dan pembelajaran TPS dikatakan berhasil.

\section{Saran}

Adapun saran yang dapat diberikan sehubungan dengan penelitian ini adalah:

1. Model pembelajaran kooperatif tipe struktural think-pair-share (TPS) dapat dijadikan sebagai alternatif bagi guru untuk diterapkan dalam pembelajaran di kelas.

2. Penelitian ini hendaknya dapat dijadikan sebagai masukan bagi peneliti lain untuk mengembangkan penelitian lebih lanjut dengan pokok bahasan berbeda.

3. Model pembelajaran kooperatif tipe struktural think-pair-share (TPS) penguasaan kelas dan materi benar-benar harus dijadwalkan dan dikuasai.

\section{DAFTAR RUJUKAN}

Ali, H. Mohammad. 1993. Strategi Penelitian Pendidikan. Bandung: Angkasa Aqip, Zainal. 2008. Penelitian Tindakan Kelas untuk Guru SMP, SMA, SMK. Bandung: Yrama Widya 
Arikunto, Suharsimi. 2002. Prosedur Penelitian. Jakarta: Rineka Cipta

Ayu, Ningrum. 2008. Pembelajaran Matematika dengan Pendekatan Kooperatif Model STAD Berorientasi Social Skill Sub Pokok Bahasan Pertidaksamaan Kuadrat pada siswa Kelas X.3 Semester Ganjil SMA Negeri 1 Kalisat Tahun Ajaran 2008/2009. Tidak dipublikasikan. Skripsi. Jember: FKIP Universitas Jember

Departemen Pendidikan Nasional. 2004. Materi Pelatihan Terintegrasi Matematika Bagian Ke-3. Jakarta

Dimyati dan Mujiono. 2006. Belajar dan Pembelajaran. Jakarta: PT. Rineka Cipta

Gulo, W. 2002. Strategi Belajar Mengajar. Jakarta: PT.Grasindo

Iryanti, Puji. 2004. Paket Pembinaan Penataran Penialaian Unjuk Kerja. Yogyakarta: Depdiknas

Kunandar. 2007. Guru Profesional Implementasi Kurikulum Tingkat Satuan Pendidikan (KTSP) dan Persiapan Menghadapi Sertifikasi Guru. Jakarta: PT. Grafindo Persada

Kurniyawati, W. R. 2004. Penerapan Pembelajaran Kooperatif Model STAD (Student Teams Achievement Division) dengan Pendekatan Konstruktivisme pada Pokok Bahasan Teorema Pythagoras Siswa Kelas IIA Semester I SMP Negeri 3 Silo Jember Tahun Ajaran 2004/2005. Tidak dipublikasikan. Skripsi. Jember: FKIP Universitas Jember

Kusniyah. 2006. Pembelajaran Logika Matematika Berorientasi Vocational Skill dengan Pendekatan Kooperatif Model STAD pada Siswa Kelas X PfL2 SMKN 2 Jember Tahun Ajaran 2005/2006. Tidak dipublikasikan. Skripsi. Jember: FKIP Universitas Jember

Muslich, Masnur. 2007. KTSP Pembelajaran Berbasis Kompetensi dan Kontekstual. Jakarta: PT. Bumi Aksara

Mutrofin. 2002. Penilaian Otentik dan Evaluasi Pembelajaran. Yogyakarta: Kurnia Kalam Semesta

Nasution. 2000. Didaktik Asas-Asas Mengajar. Jakarta: Bumi Aksara

Rusyan, A. Tabrani , Atong Kusdinar, Zainal Arifin. 1992. Pendekatan dalam Proses Belajar Mengajar. Bandung: PT. Remaja Rosdakarya

Sahlan, Moh. 2007. Penilaian Berbasis Kelas Teori dan Aplikasi dalam Kurikulum Tingkat Satuan Pendidikan (Kurikulum 2006). Jember: Center for Society Studies Jember

Slameto.1995. Belajar dan Faktor-faktor yang Mempengaruhinya. Jakarta: Rineka Cipta Sudjana. 1992. Penilaian Hasil Proses Belajar Mengajar. Bandung: Remaja Rosdakarya Sunardi. 2006. Model Pembelajaran Berbasis Prinsip-prinsip KBM. (Disampaikan dalam pelatihan Peningkatan kompetensi Pedagogik Guru-guru SMAN 2 Bondowoso pada tanggal 18 Maret 2006). Jember: FKIP Universitas Jember

Widyawati, L. 2005. Pembelajaran Matematika Berorientasi Social Skill Didasarkan pada Tahapan J.Bruner Pokok Bahasan Aritmetika Sosial Kelas IC Semester I SMP Negeri 12 Jember Tahun Ajaran 2004/2005. Tidak dipublikasikan. Skripsi. Jember: FKIP Universitas Jember

Wiyandini. 2005. Pembelajaran Volum: Tabung, Kerucut, dan Bola dengan Model ARIAS pada Siswa Kelas VIIA Semester Genap SMP Negeri 3 Jember Tahun Ajaran 2004/2005. Tidak dipublikasikan. Skripsi. Jember: FKIP Universitas Jember 